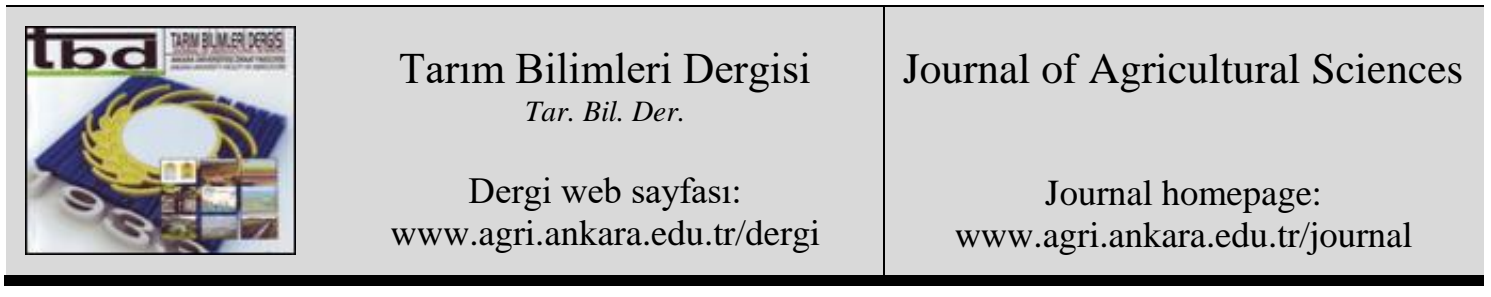

\title{
The Impact of Livestock Supports on Production and Income of the Beef Cattle Farms: A Case of Samsun Province, Turkey
}

\author{
Nevra ALHAS EROGLU ${ }^{\mathrm{a}}$, Mehmet BOZOGLU ${ }^{\mathrm{b}}$, Abdulbaki BILGIC \\ $a_{\text {Regional Directorate of Turkish Statistical Institute, Samsun, TURKEY }}$ \\ ${ }^{b}$ Department of Agricultural Economics, College of Agriculture, Ondokuz Mayis University, Samsun, TURKEY \\ ${ }^{c}$ Department of Agricultural Economics, College of Agriculture, Ataturk University, Erzurum, TURKEY
}

\section{ARTICLE INFO}

Research Article

Corresponding Author: Nevra ALHAS EROGLU, E-mail: nevraalhas@ @uik.gov.tr, Tel: +90 (505) 7789279

Received: 26 November 2018, Received in Revised Form: 28 January 2019, Accepted: 12 February 2019

\section{AUTHORS ORCID ID}

(Nevra ALHAS EROGLU: 0000-0002-1188-8274), (Mehmet BOZOGLU: 0000-0001-8333-1865), (Abdulbaki BILGIC: 0000-0002-1003-7072)

\begin{abstract}
Although the beef cattle sector has been considerably supported during the last two decades, Turkey could not get its self-sufficiency yet. The objective of this case study was to examine the impacts of livestock supports on production and income of beef cattle farms. The survey data was collected from randomly selected 171 cattle farms in Samsun province of Turkey. The Treatment Effect Model was used to measure the impacts of livestock supports on beef meat production and gross profit of the farms. The results indicate that the farmers, who have larger land and herd, higher
\end{abstract}

education level, keeping farm records, are mechanized and specialized in beef cattle breeding were more likely to benefit from livestock supports than their counterparts. The Treatment Effect Model highlights that livestock support has a statistically significant effect on the amount of beef meat produced whereas it has no statistically significant effect on the gross profits of the farms. The research recommended that the livestock supports are necessary for the sustainability of beef cattle farms. The farms should be encouraged to get records via Farm Accountancy Data Network and the record keeping farms should be supported by higher amounts.

Keywords: Beef cattle breeding; Livestock supports; Impact assessment; Treatment effect; Turkey

\section{Introduction}

(C) Ankara Üniversitesi Ziraat Fakültesi

The livestock sector is of an important place in the agricultural sector of the world. Thus, $38.6 \%$ of the gross production value of agricultural production in the world was provided by the livestock sector in 2016. In the same year, in Turkey, the livestock sector provided $34.5 \%$ of total agricultural production value (FAO 2018). In the last decade, the livestock sector has been substantially supported both in Turkey and in the world due to its essential role by meeting food demand and supplying input to the agro-food industry. Therefore, the evaluation of the impacts of supports on production and income of the beef cattle farms is essential to develop more efficient support policies.

The development of the livestock sector is important to meet the food need of countries. Therefore, it is essential to maintain the sustainability of the sector, to improve it by means of supports and to assess 
the impacts of the supports. In the period of 2000-2016, in Turkey, the budget of total agricultural supports had nominally changed from $\$ 4.5$ to $\$ 3.97$ billion whereas the budget of livestock supports had increased from $\$ 0.02$ to $\$ 1.02$ billion. The share of the livestock supports in the total agricultural supports had increased from $0.5 \%$ to $25.7 \%$ in the same period (Anonymous 2015).

The main output of the sector is definitely beef meat. In the last two decades, the number of slaughtered beef had increased by $214 \%$ and the production of beef meat had increased by $351 \%$ in Turkey (TurkStat 2018a). While the producer prices had increased nominally, there had not been a significant increase in reel prices except for the last few years. Because of inadequacies in domestic beef meat production, continuously rises in consumer prices, the country had to import breeding material, live animal or beef meat. Therefore, there had been an important rise in import especially after the year 2010 .

The costs of the beef cattle breeding activity is another disputable field. The major cost of the beef meat production is feed. This cost constituted about 40.95\% (Alhas Eroğlu 2017), 33.1\% (Çelik \& Sarı̈özan 2017) and 48.3\% (Özkan \& Erkuş 2003) of the total cost of production. The increase in this main cost element pushes up beef meat prices. The parity between beef meat and forage increased by $25.7 \%$, whereas the parity between beef meat and milk increased by $28.1 \%$ during the period of 1994-2017. This data could be interpreted in favor of the cattle beef producers but the negative developments for dairy sector have affected dairy cattle sector and resulted in difficulties in obtaining breeding material and increasing in beef meat production costs and prices. The government has supported forage and roughage crops to increase production. These supports had increased both in sown areas and production of forage and roughage crops. Nevertheless, rising especially in price of concentrate feeds have negatively affected the production cost of beef meet.

The livestock supports have been provided with farms in the last twenty years in order to get sustainability in the sector. Of all livestock supports, both breeding male cattle and forage crop support are of great importance and directly affect the beef cattle farms. Breeding male cattle supports have been granted for the farms that slaughtered one year old and at least $200 \mathrm{~kg}$ carcass weighted male cattle and record it to the official system. It was granted since 2011 but the unit price of the support has been decreasing over the time. The forage crop support has been granted for farms in order to decrease the feed cost. The farmers who have grown clover, corn, sainfoin, etc. at least 1 ha officially recorded land could provide with support. Contrary to breeding male support, the unit price of forage crop support has risen over the years. Although the sector has been seriously supported for 15 years, there have been some considerable problems such as supplying adequate breeding materials, rising feed cost and beef meat prices and increasing import. Therefore, the impacts of the cattle support on production and prices make these policies controversial. Though the sector received $30 \%$ of total agricultural supports, the cattle breeding sector has some important obstacles such as depending on external inputs like feed and breeding material, the prevalence of small-scale farm sizes. Therefore, the efficiency of the support policies has been disputable (Anonymous 2018). The assessment of the impacts of direct supports is highly essential for the beef cattle sector.

Literature review shows that the number of the studies concerning the impacts of agricultural support policies had considerably increased in recent year. The majority of this literature addressed the impacts of decoupled payments. Although the impacts of agricultural supports had been explored in a broad context including farmer, farm structure, input use, production, income and environment, the emphasis of the literate has been mainly on production and income of farms. The literature about the impacts of agricultural supports on production and income has mainly concentrated on the three different scenarios such as supports have (i) no effect, (ii) positive effect and (iii) negative effect. A number of studies identified decreasing impacts of agricultural supports on production and income (Chau \& de Gorter 2000; Moss et al 2002; Breen et al 2005; Goodwin \& Mishra 2005; Goodwin \& Mishra 2006; Shrestha et al 2007; Gorton et al 2008; Acs et al 2010; Morgan-Davies et al 2012; Kazukauskas et al 2014). Some of them highlighted that the changes of supports decreased production due to the reduction of cattle number (Moss et al 2002; Shrestha et al 2007; Acs et al 2010; Morgan-Davies et al 2012), while Breen et al (2005) stated that some of the producers terminated production activity. Chau \& de Gorter (2000) and Gorton et al (2008) stressed that thank to the supports, the farms continued to produce regardless of profit. 
Numerous research results indicated that the agricultural supports had an increasing impact on production and income of the farms (Hennessy 1998; Sckokai \& Moro 2006; Revell \& Oglethorpe 2003; O’Donoghue \& Whitaker 2010; Majewski et al 2011; Viaggi 2011; El Benni et al 2012; Bartolini \& Viaggi 2013; Severini \& Tantari 2013). In addition to income-boosting effect, the agricultural supports decrease volatility and inequality in income (El Benni et al 2012; Severini \& Tantari 2013). However, Hennessy (1998) and Sckokai \& Moro (2006) stated that agricultural supports have decreased the degree of risk by reducing income variability faced by farmers. Some researcher stressed that without agricultural supports the further number of producers would be likely to end up their production (Majewski et al 2011; Viaggi 2011; Bartolini \& Viaggi 2013).

Some literature highlighted that agricultural supports had neither an increasing nor decreasing impact on production and income (Douarin et al 2007; Genius et al 2008; Lobley \& Butler 2010; Weber \& Key 2012; Giannoccaro \& Berbel 2013; Latruffe et al 2013). Thus, 66\% of the producers in the study of Latruffe et al (2013) and $62 \%$ of the producers in the study of Lobley \& Butler (2010) did not change the amount of production in case of no support scenario.

Contrary to the international literature, in Turkey, there have been limited studies concerning the impact of supports on the livestock sector. Of all, the impacts of supports were examined at the levels of provincial, regional or countrywide using secondary data or primary survey data (Topçu 2008; Y1lmaz et al 2008; Topçu et al 2008; Demir 2009; Demir \& Yavuz 2010; Keskin et al 2010; Aksoy et al 2012; Özüdoğru \& Tatlidil 2012). Aksoy et al (2012) indicated that the livestock supports during the period of 2002-2009 had not an effect on milk production and suggested that it is essential to design support policies at the regional level. This suggestion was also emphasized by other scholars in order to increase efficiency (Demir 2009; Keskin et al 2010; Demir \& Yavuz 2010). While Yllmaz et al (2008) stated that the supports increase the inequality of income distribution; Özüdoğru \& Tatlıdil (2012) indicated that unionized producers could reduce their cost by benefiting from supports. These empirical studies mostly examined the effects of supports on production and income of the dairy farms. Despite the increase in beef prices in Turkey and government supports, the beef meat production could not be increased to the expected levels of the country. Therefore, it is essential to evaluate the impacts of cattle support policies at the farm level. The objective of this study was to explore the impacts of cattle breeding supports on the production and gross profit of beef cattle farms in Samsun province of Turkey by using the treatment effect model (TEM). The average treatment effect (ATE) and the average treatment effect on the treated farms (ATET) have been put forward in terms of direction, size, and statistics in the current study.

This paper is structured as follows: after the introduction, main developments of the beef cattle sector in Turkey and the essence of the study was described in the next section. The data and methodology were specified in the third section. In the fourth section, descriptive statistics and the model results were introduced. In the last section, conclusions with policy recommendations were presented.

\section{Material and Methods}

\subsection{Research area}

The research area, Samsun province, has located in the Black Sea Region. It has $9352 \mathrm{~km}^{2}$ acreages and it consists of approximately $1 \%$ of total area of Turkey. In $2017,1.61 \%$ of the total agricultural land in Turkey has located in Samsun province (TurkStat 2018b). In the same year, the value shares of crop production, livestock and animal products of Samsun province in the country value were $2.40 \%, 1.80 \%$, and $0.72 \%$, respectively. The share of the total production value of Samsun province in Turkey was 1.82\% (TurkStat 2018c).

The support of breeding male cattle has been given to the farms since 2011 and Samsun province had received about $1.3 \%$ of the total support (Anonymous 2016). Whereas, the share of Samsun province in total cattle and beef cattle number of Turkey were $2.42 \%$ and $2.69 \%$, respectively (TurkStat 2018c). This figure indicates that Samsun could not sufficiently benefit from the supports. 


\subsection{Material}

The research population consisted of 799 beef cattle farms which were members of two Beef and Lamb Producers Associations in Samsun province. In the study, 137 farms were selected randomly using strata sampling method with the farms that have less than 130 cattle and 34 cattle farms having than 130 cattle were determined using census method ${ }^{1}$. The total number of surveyed beef cattle farms was 171 . The sampling method is determined with $99 \%$ a confidence interval and $1 \%$ of error. The sampling procedure was presented in Equation 1 and Table 1 (Yamane 2001).

$n=\frac{N \sum\left(N_{h} S_{h}^{2}\right)}{N^{2} D^{2}+\sum\left(N_{h} S_{h}^{2}\right)}$

Where; $n$, sample size for the strata of I and II (137); $N$, population size (761); $N_{h}$, number of units in the strata of $\mathrm{h} ; S_{h}$, the standard deviation in the strata of $\mathrm{h} ; D^{2}=d^{2} / Z^{2} ; d$, level of precision (acceptable sampling error); $z$, the value from $\mathrm{z}$ score table.

Table 1- The population and sample of the research

\begin{tabular}{ccccc}
\hline Strata & $\begin{array}{c}\text { Strata range } \\
\text { (per cattle) }\end{array}$ & $N$ & $n$ & Method \\
\hline I & $1-59$ & 628 & 110 & Sample \\
II & $60-129$ & 133 & 27 & Sample \\
III & $130+$ & 34 & 34 & Census \\
Total & --- & 799 & 171 & - \\
\hline
\end{tabular}

\subsection{Method}

In this research, Treatment Effect Model was used to analyze the impacts of supports on production and gross profit of beef cattle farms. TEM is used to estimate the impacts of a treatment and evaluate the probable outcome of it. In the model, there is a treatment that is farms which receive a support from the government. This model is used to determine the difference between the state where the farmer does not receive support and the state he/she receives. If the difference is positive and statistically significant, there is an incentive for the sustainability of support; otherwise, it means that other plans should be considered. However, the information of the farmer in the absence of support is sometimes not fully achieved. For this purpose, it integrates the farmers who do not receive support but they are totally similar in sociodemographic and economic characteristics with farmers who receive the support in order to put the difference between the two states. The aim of the empirical model is to determine whether this treatment has an impact on response variable and if has, the direction of this impact (Hsieh 2009).

Let outcome $y_{j}$, treatment $t_{j}$, error term $\varepsilon_{j}$ and the vector of all exogeneous covariates $z_{j}=\left(w_{j} x_{j}\right)$, the equation can be denoted;

$E\left(y_{j} \mid x_{j}, t_{j}, \varepsilon_{j}\right)=\exp \left(x_{j} \beta+\delta t_{j}+\varepsilon_{j}\right)$

Where; $y_{0 j}$ is potential outcome without treatment $\left(t_{j}=0\right), y_{1 j}$ is potential outcome with treatment $\left(t_{j}=1\right), \beta_{0}$ and $\beta_{1}$ are coefficients for the control and treatment regimens and let the potential outcome model be;

$E\left(y_{0 j} \mid x_{j}, \varepsilon_{j}\right)=\exp \left(x_{j} \beta_{0}+\varepsilon_{0 j}\right)$

$E\left(y_{1 j} \mid x_{j}, \varepsilon_{j}\right)=\exp \left(x_{j} \beta_{1}+\varepsilon_{1 j}\right)$

${ }^{1}$ Although there were 38 cattle farms in the third strata, 4 of them were unanswered because of repetition and merging of farms. 
$t_{j}=\left\{\begin{array}{c}1, w_{j} \gamma+u_{j}>0 \\ 0, \text { otherwise }\end{array}\right\}$

In the binary model, $y_{0 j}$ and $y_{1 j}$ have never been observed together and it can be denoted;

$y_{j}=t_{j} y_{1 j}+\left(1-t_{j}\right) y_{0 j}$

Average treatment effect and average treatment effect on the treated are the major parameters of the TEM model. ATE refers to the average treatment effect and it is the average difference of treatment and control potential outcomes and estimated by;

$$
\begin{aligned}
A T E & =E\left[\left\{\exp \left(x_{j} \beta_{1}\right)-\exp \left(x_{j} \beta_{0}\right)\right\} \exp \left(\frac{\sigma^{2}}{2}\right)\right] \\
& =E\left\{E\left(y_{1 j}-y_{0 j} \mid z_{j}\right)\right\}=E\left(y_{1 j}-y_{0 j}\right)
\end{aligned}
$$

On the other hand, ATET refers to the average treatment effect on the treated and it is the average effect of treatment on outcome compared with no treatment for a random draw from the subpopulation selecting (or assigned) no treatment (Rubin 1974; Heckman \& Robb 1985; Terza 1998; Angrist 2001).

$$
\begin{aligned}
\text { ATET } & =\left[\left\{\exp \left(x_{j} \beta_{1}\right)-\exp \left(x_{j} \beta_{0}\right)\right\} \exp \left(\frac{\sigma^{2}}{2}\right) \frac{\Phi\left(\rho \sigma+w_{j} \gamma\right)}{\Phi w_{j} \gamma} \mid t_{j}=1\right] \\
& =E\left\{E\left(y_{1 j}-y_{0 j} \mid z_{j}, t_{j}=1\right) \mid t_{j}=1\right\}=E\left(y_{1 j}-y_{0 j} \mid t_{j}=1\right)
\end{aligned}
$$

In this study, livestock supports are taken account as treatment and the impacts of this treatment on beef meat production and gross profit were estimated. The model is based on the three assumptions such as the livestock supports have (i) no effect, (ii) increase effect or (iii) decrease effect on the amount of beef meat produced and gross profit of the farms.

\section{Results and Discussion}

\subsection{Descriptive analysis}

The descriptive statistics are presented in Table 2 . The results of the study indicate that $50.9 \%$ of beef cattle farms were specialized in the beef cattle breeding and $57.3 \%$ of them were keeping physical or financial records. About $25 \%$ of cattle farms employed permanent labor for beef cattle breeding, whereas $59.1 \%$ of them employed temporary labor. About $64 \%$ of total farms were small-scale owning less than 60 cattle. The average gross profit of farms was $\$ 60435.23^{2}$. About $95 \%$ of beef cattle farms benefited from $\$$ 4969.73 of total agricultural support, whereas $80.1 \%$ of farms benefited from $\$ 2425.19$ of fattening male cattle and forage crop supports. The share of fattening male cattle and forage crop supports into the total agricultural supports was $48.8 \%$. The farms spent $90 \%$ of the support revenues for agricultural activities.

The cattle farms were averagely $8.25 \mathrm{~km}$ far from the district center and $40.4 \%$ of them have located in Bafra and Çarşamba districts. The average agricultural land was 10.7 ha and $32.2 \%$ of farms had 10 ha or more agricultural land. However, average agricultural land was found 15.8 ha for the unionized and 7.1 ha non-unionized farmers in the study of Özüdoğru \& Tatlıdil (2012). The average agricultural land of Goodwin \& Mishra (2005; 2006), Latruffe et al (2013) and Giannoccaro \& Berbel (2013) is above the result of this research whereas it is below in the research of Majewski et al (2011). About 82\% of the farms grew forage crops.

\footnotetext{
${ }^{2}$ In the field research period, the average exchange rate of TL/ is 2.33
} 
The average membership duration in Turkish Beef and Lamb Producers Associations was 4.29 years and $3.5 \%$ of farm managers participated in the governance of the association. Besides, $61.4 \%$ of beef cattle farms were a member of other farmer organizations. Majewski et al (2011) stated the proportion of unionization as 54\% whereas it was estimated 55\% and 79.7\% in Giannoccaro \& Berbel (2013) and Gorton et al (2008), respectively. About $76 \%$ of the farms had non-agricultural income. About $91 \%$ of the farms own one or more agricultural machines and $53.8 \%$ of the farms had tractor and trailer.

The farms had averagely 6.84 household members. About $73 \%$ of householders' main profession was a farmer, whereas $14 \%$ of them perform the beef cattle breeding activity with other profession. Therefore, $87.7 \%$ of the farms directly conduct cattle breeding activity. While $68.18 \%$ of households were within the economic active age group (15-64 age), main profession of $83.6 \%$ of them is farmer. The average age of managers was 49.16 years and average experience in beef cattle farming was 20.19 years. About $64.91 \%$ of managers graduated from primary school, whereas $17.5 \%$ of them graduated from high school or above. The share of high school graduates was found as 65\% in the study of Majewski et al (2011) and 13.5 years in the study of Gorton et al (2008).

Table 2- Descriptive statistics of beef cattle farms

\begin{tabular}{|c|c|c|}
\hline Variables & Mean & Std. dev. \\
\hline \multicolumn{3}{|l|}{ Cattle farming } \\
\hline Specialized in beef cattle breeding $(\mathrm{Yes}=1, \mathrm{No}=0)$ & 0.509 & 0.501 \\
\hline Keeping record $(\mathrm{Yes}=1, \mathrm{No}=0)$ & 0.573 & 0.496 \\
\hline Temporary labor employment $(\mathrm{Yes}=1, \mathrm{No}=0)$ & 0.591 & 0.493 \\
\hline Permanent labor employment $(\mathrm{Yes}=1, \mathrm{No}=0)$ & 0.251 & 0.435 \\
\hline Cattle farm size is between 1 and 59 beefs $(\mathrm{Yes}=1, \mathrm{No}=0)$ & 0.643 & 0.480 \\
\hline Gross profit (\$) & 60435.23 & 109034.38 \\
\hline Benefit from cattle breeding supports $(\mathrm{Yes}=1, \mathrm{No}=0)$ & 0.801 & 0.400 \\
\hline \multicolumn{3}{|l|}{ Farm structure } \\
\hline Distance of the farm to the district center $(\mathrm{km})$ & 8.257 & 6.855 \\
\hline The farm is situated in Bafra ve Çarşamba districts $(\mathrm{Yes}=1, \mathrm{No}=0$ ) & 0.404 & 0.492 \\
\hline Household size (unit) & 6.842 & 3.767 \\
\hline Farm size is over 10 ha $(\mathrm{Yes}=1, \mathrm{No}=0)$ & 0.322 & 0.468 \\
\hline Growing fodder crop $(\mathrm{Yes}=1, \mathrm{No}=0)$ & 0.819 & 0.386 \\
\hline $\begin{array}{l}\text { Membership duration into the Beef and Lamb Producers Association } \\
\text { (year) }\end{array}$ & 4.292 & 1.903 \\
\hline $\begin{array}{l}\text { Participation in the management of the Management of Beef and } \\
\left.\text { Lamb Producers Association (Yes }=1, \mathrm{No}_{0}=0\right)\end{array}$ & 0.035 & 0.185 \\
\hline Membership of other farmer organizations $(\mathrm{Yes}=1, \mathrm{No}=0)$ & 0.614 & 0.488 \\
\hline Have non-agricultural income $($ Yes $=1, \mathrm{No}=0)$ & 0.760 & 0.428 \\
\hline Tractor and trailer ownership $(\mathrm{Yes}=1, \mathrm{No}=0)$ & 0.538 & 0.500 \\
\hline Other agricultural machines ownership $(\mathrm{Yes}=1, \mathrm{No}=0)$ & 0.906 & 0.292 \\
\hline \multicolumn{3}{|l|}{ Manager } \\
\hline The main profession as farmer $(\mathrm{Yes}=1, \mathrm{No}=0)$ & 0.877 & 0.329 \\
\hline The cattle farming experience (year) & 20.199 & 11.022 \\
\hline High school or higher education $(\mathrm{Yes}=1, \mathrm{No}=0)$ & 0.175 & 0.381 \\
\hline Agricultural supports (\$) & 4969.73 & 8238.30 \\
\hline Cattle breeding supports $(\$)$ & 2425.19 & 3614.39 \\
\hline
\end{tabular}

About $71 \%$ of cattle farms were satisfied with the cattle breeding activity. Nevertheless, the major reason of dissatisfaction was stated as high cost of production and inadequacy of supports. About $49 \%$ of the farms intended to increase the number of cattle in the near future. The fundamental problems of the farms were stated as increase in forage prices, an inadequacy of support policies and negative effects of cattle import on production and prices. Aydın et al (2010) found that $31.7 \%$ of the farmers have not considered the increase in supports as a solution for a rise in beef meat prices. However, Goodwin $\&$ Mishra (2005) highlighted that $54 \%$ of the farmers consider the costs as the main element of production decision. 
The amount of supports was not seen sufficient by $66.7 \%$ of the farmers and $40.4 \%$ of the farmers stated that support payments were not paid on time. Almost half of the farmers stated that the announcement of supports was not enough and the application procedure of the supports takes much time due to the red tape (Table 3).

Table 3- The problems facing with utilization of supports

\begin{tabular}{|c|c|c|c|c|c|c|c|}
\hline Problem area & $\begin{array}{l}\text { 1. Strongly } \\
\text { disagree }\end{array}$ & 2. Disagree & 3. Neutral & 4. Agree & $\begin{array}{l}\text { 5. Strongly } \\
\text { agree }\end{array}$ & $\begin{array}{l}\text { Total } \\
\text { score }\end{array}$ & Rank \\
\hline $\begin{array}{l}\text { The amount of support is } \\
\text { not sufficient }\end{array}$ & 1.2 & 7.6 & 1.2 & 23.3 & 66.7 & 764 & 1 \\
\hline Supports are not paid on time & 11.7 & 40.4 & 1.1 & 21.1 & 25.7 & 528 & 2 \\
\hline $\begin{array}{l}\text { The request of support takes } \\
\text { much time due to red tape }\end{array}$ & 15.8 & 35.1 & 1.7 & 18.7 & 28.7 & 529 & 3 \\
\hline $\begin{array}{l}\text { The announcement of } \\
\text { supports isn't adequate }\end{array}$ & 25.1 & 29.2 & 0.6 & 32.2 & 12.9 & 476 & 4 \\
\hline $\begin{array}{l}\text { The supports could be } \\
\text { confiscated due to debt, } \\
\text { sponsorship etc. }\end{array}$ & 29.9 & 33.9 & 2.3 & 14.0 & 19.9 & 445 & 5 \\
\hline
\end{tabular}

The main expectations of the farms on cattle breeding were stated respectively as getting stability in cattle and meat prices, reducing forage prices, enhancing and revising supports in respect to quality, hygiene and amount of meat, paying supports on time and enhancing extension opportunities (Table 4).

Table 4- The expectations of the farms on cattle breeding

\begin{tabular}{|c|c|c|c|c|c|c|c|}
\hline Type of expectation & $\begin{array}{l}\text { 1. Strongly } \\
\text { disagree }\end{array}$ & 2. Disagree & 3. Neutral & 4. Agree & $\begin{array}{l}\text { 5.Strongly } \\
\text { agree }\end{array}$ & $\begin{array}{l}\text { Total } \\
\text { score }\end{array}$ & Rank \\
\hline $\begin{array}{l}\text { The price of cattle and meat } \\
\text { should be stable }\end{array}$ & 0.6 & 0 & 1.2 & 18.7 & 79.5 & 815 & 1 \\
\hline $\begin{array}{l}\text { The price of forage should } \\
\text { be decreased }\end{array}$ & 0.6 & 1.2 & 2.3 & 16.4 & 79.5 & 809 & 2 \\
\hline $\begin{array}{l}\text { The amount of supports } \\
\text { should be increased }\end{array}$ & 0 & 4.7 & 1.2 & 12.3 & 81.9 & 806 & 3 \\
\hline $\begin{array}{l}\text { The supports should be } \\
\text { paid on time }\end{array}$ & 0 & 0 & 4.7 & 41.2 & 54.1 & 764 & 4 \\
\hline $\begin{array}{l}\text { The producers should be } \\
\text { provided with more } \\
\text { extension opportunities } \\
\text { about breeding }\end{array}$ & 1.8 & 2.3 & 1.8 & 47.4 & 46.8 & 744 & 5 \\
\hline $\begin{array}{l}\text { The supports should be } \\
\text { focused on quality, hygiene } \\
\text { and amount of production }\end{array}$ & 8.2 & 2.9 & 3.5 & 31.0 & 54.4 & 719 & 6 \\
\hline $\begin{array}{l}\text { Membership fee of the } \\
\text { unions should be lessened. }\end{array}$ & 1.2 & 14.0 & 10.5 & 28.7 & 45.6 & 690 & 7 \\
\hline $\begin{array}{l}\text { The supports should be } \\
\text { seasonally organized }\end{array}$ & 2.9 & 26.3 & 10.5 & 21.6 & 38.6 & 627 & 8 \\
\hline
\end{tabular}

\subsection{Treatment effect model results}

TEM model was analyzed for both production (beef meat) and gross profit. The log-likelihood value and sigma $(\sigma)$ value was measured -241.445 and 0.776 for beef meat model and -340.112 and 1.495 for gross profit model. Rho $(\rho)$ parameter shows that one standard deviation in the probability of benefit from supports resulted in 0.39 standard deviation in beef meat production and 0.02 standard deviation in gross profit. But these effects were not found statistically significant. 
Even though there is no relationship between the probability of cattle breeding supporting system and the amount of meat production and gross profit when taking non-controlled factors into account (e.g., correlation coefficients), the results of the model highlight that cattle breeding supports had positive statistically significant effect on production of beef meat. Therefore, these supports are essential to boost beef meat production and to ensure economic sustainability of beef cattle sector. On the other hand, cattle breeding supports had statistically insignificant effect on gross profit. By the way, this effect indicates that cattle farms could not be financially well-managed. Besides, the statistically insignificant effect can be explained by the high costs of production in the farms that was not get benefit from the livestock supports.

According to the beef meat production and gross profit TEM results, cattle farms which are situated in Çarşamba and Bafra districts and keeping farm records were more likely to benefit from livestock supports than their counterparts. On the other hand, the gross profit model resulted that the farms that have land larger than 10 ha were also more likely to benefit from livestock supports. The effect of location can be explained by some reasons. First of all, beef cattle farms in Bafra and Çarşamba the districts were relatively large-scaled, closer to district center and had easier access to information sources of supports. Besides, one of the Beef and Lamb Producers Association has located in Bafra district. The higher probability of benefiting from subsidy for the farms keeping records can be explained by their advantages such as management, planning, and technology. Lastly, the farms that have 10 ha or larger land grow forage crops and provide the roughage requirement of their farms. Therefore, it enables the farms to decrease their production costs and increase their profitability.

The results of beef meat production and gross profit models were presented in Table 5 . The results indicate that supports, specialization, keeping a record, employing permanent labor and having higher mechanization level had statistically significant positive effects on beef meat production. On the other hand, the location of the farm and non-agricultural income had a statistically significant negative effect on beef meat production. Benefiting from higher supports by the farms in Çarşamba and Bafra districts decrease production risk and negatively affect the expansion of the scale of farms. The farms that have nonagricultural income produce less beef meat than the other farms. This shows that that non-agricultural income prevents farms from specialization and expansion of the scale.

The results of the gross profit model indicate that the participation into the management of Beef and Lamb Producers Association, higher mechanization and education level of a manager (high school or over) had statistically significant positive effects on beef meat production, whereas ownership of tractor and trailer had statistically significant negative effects. The farms whose manager participated in the management of Beef and Lamb Producers Association had higher gross profit than their counterparts. Because they had more chance to get technical assistance, cheaper input and market their products with better conditions by the association. Although the gross profit of the farms which had the modern machines for cattle farming was higher than the others, the gross profit of the farms which had tractor and trailer was lower than the other farms. The farms who own tractor and trailer concentrate on crop production and their beef meat production and gross profit was lower than their counterparts. Lastly, the farms whose education level of a householder with high school or higher education had higher gross profit than their counterparts. This parameter shows that education had a positive effect on the profitability of the farm because education is essential on adoption and application of new technologies.

ATE and ATET of beef meat production and gross profit models are presented in Table 6. Cattle breeding supports increase the meat production by $11760 \mathrm{~kg}$ and the gross profit by $\$ 8025.75$ on average. Among the farms that are supported (treated), the beef meat production of a farm increase by $12620 \mathrm{~kg}$ when it is supported compared with the case that it is not supported and the coefficient of production is statistically significant. On the other hand, though the gross profit also increases by $\$ 7811.15$ in this comparison, the results of the research highlight that the coefficient of gross profit is not statistically significant. Therefore, we can say that cattle breeding supports significantly increase average meat production in the region. At the same time, this increase is more important among the beneficiaries (e.g., the treated farms). However, although the increase in gross profit is not statistically significant, the estimated values can be attributed to increased production costs. The optimal use of inputs used in meat production can make gross profit more advantageous and make the use of supports more sustainable. 
Table 5- TEM results for beef meat production and gross profit of cattle farms

\begin{tabular}{|c|c|c|c|c|c|c|c|c|}
\hline \multirow[t]{2}{*}{ Variables } & \multicolumn{2}{|c|}{$\begin{array}{c}\text { Probability of } \\
\text { being supported }\end{array}$} & \multicolumn{2}{|c|}{$\begin{array}{l}\text { Production value } \\
\text { (log) }\end{array}$} & \multicolumn{2}{|c|}{$\begin{array}{l}\text { Probability of } \\
\text { being supported }\end{array}$} & \multicolumn{2}{|c|}{ Gross profit } \\
\hline & Coefficient & $t$-value & Coefficient & $t$-value & Coefficient & t-value & Coefficient & $t$-value \\
\hline $\begin{array}{l}\text { Constant } \\
\text { Cattle farming }\end{array}$ & 1.6702 & 0.9825 & $-1.7181 * * *$ & -2.8464 & 1.2876 & 0.8007 & -1.0174 & -0.6983 \\
\hline $\begin{array}{l}\text { Specialized in beef } \\
\text { cattle breeding }\end{array}$ & 0.7328 & 1.5828 & $0.6573 * * *$ & 3.0660 & 0.6588 & 1.4490 & 0.3557 & 0.8852 \\
\hline Keeping record & $0.8850 *$ & 1.7513 & $0.4359 * *$ & 2.1190 & $0.8832 *$ & 1.8484 & 0.3594 & 0.6986 \\
\hline $\begin{array}{l}\text { Temporary labor } \\
\text { employment }\end{array}$ & -0.1737 & -0.4387 & 0.1807 & 1.0282 & -0.0944 & -0.2588 & 0.1928 & 0.5114 \\
\hline $\begin{array}{l}\text { Permanent labor } \\
\text { employment }\end{array}$ & -0.2803 & -0.3016 & $0.5103 * *$ & 2.3811 & -0.0004 & -0.0005 & 0.6437 & 1.5389 \\
\hline $\begin{array}{l}\text { Cattle farm size is } \\
\text { between } 1 \text { and } 59 \text { beefs } \\
\text { Farm Structure }\end{array}$ & -1.4818 & -1.3863 & - & - & -1.2239 & -1.4250 & - & - \\
\hline $\begin{array}{l}\text { Distance of the farm to } \\
\text { the district center }(\mathrm{km})\end{array}$ & -0.0053 & -0.1239 & 0.0077 & 0.5301 & -0.0074 & -0.1718 & 0.0342 & 1.2735 \\
\hline $\begin{array}{l}\text { The farm is situated in } \\
\text { Bafra and Çarşamba } \\
\text { districts }\end{array}$ & $1.1204 * *$ & 2.2191 & $-0.4423^{*}$ & -1.8916 & $1.0572 * *$ & 2.2412 & -0.4358 & -1.0114 \\
\hline Household size (unit) & 0.0189 & 0.2570 & 0.0211 & 0.8065 & 0.0174 & 0.2484 & -0.0273 & -0.6112 \\
\hline Farm size is over 10 ha & 0.7427 & 1.1769 & -0.1640 & -0.7802 & $0.8162 *$ & 1.7266 & -0.0107 & -0.0210 \\
\hline Growing fodder crop & - & - & -0.3469 & -1.5379 & - & - & -0.4494 & -1.0910 \\
\hline $\begin{array}{l}\text { Membership duration } \\
\text { into the Beef and Lamb } \\
\text { Producers Association } \\
\text { (year) }\end{array}$ & -0.1576 & -1.4325 & 0.0155 & 0.3450 & -0.1451 & -1.1662 & 0.1262 & 1.2560 \\
\hline $\begin{array}{l}\text { Participation in the } \\
\text { Management of Beef } \\
\text { and Lamb Producers } \\
\text { Association }\end{array}$ & -1.0688 & -0.7190 & 0.5110 & 0.7160 & -0.9306 & -0.6811 & $1.5275^{* *}$ & 2.5064 \\
\hline $\begin{array}{l}\text { Membership of other } \\
\text { farmer organizations }\end{array}$ & -0.6708 & -1.1975 & -0.0249 & -0.1278 & -0.7035 & -1.3009 & -0.6753 & -1.6539 \\
\hline $\begin{array}{l}\text { Have non-agricultural } \\
\text { income }\end{array}$ & 0.2437 & 0.4600 & $-0.3456^{*}$ & -1.6560 & 0.2112 & 0.4240 & 0.0589 & 0.1398 \\
\hline $\begin{array}{l}\text { Tractor and trailer } \\
\text { ownership }\end{array}$ & -0.2379 & -0.2751 & $0.6042 *$ & 1.7977 & -0.2302 & -0.3154 & $1.4370^{*}$ & 1.9332 \\
\hline $\begin{array}{l}\text { Other agricultural } \\
\text { machines ownership } \\
\text { Manager }\end{array}$ & 0.1434 & 0.2615 & -0.2719 & -1.4830 & 0.0882 & 0.2074 & $-0.6655^{*}$ & -1.7311 \\
\hline $\begin{array}{l}\text { The main/second } \\
\text { profession as farmer }\end{array}$ & 0.0045 & 0.0071 & -0.1769 & -0.7496 & 0.1953 & 0.3301 & 0.2530 & 0.3623 \\
\hline $\begin{array}{l}\text { The cattle farming } \\
\text { experience (year) }\end{array}$ & 0.0076 & 0.3603 & -0.0008 & -0.1040 & 0.0095 & 0.4628 & -0.0016 & -0.1092 \\
\hline $\begin{array}{l}\text { Education level is } \\
\text { equal or over high } \\
\text { school }\end{array}$ & -0.1937 & -0.3101 & 0.2292 & 1.0478 & -0.2353 & -0.3742 & $0.9100 * *$ & 2.2800 \\
\hline $\begin{array}{l}\text { Benefit from cattle } \\
\text { breeding supports }\end{array}$ & - & - & $1.4778 * * *$ & 3.1693 & - & - & 0.2760 & 0.1619 \\
\hline$\sigma$ & 0.7761 *** & 12.2346 & & & $1.4953 * * *$ & 15.308 & & \\
\hline$\rho$ & -0.3969 & -1.0522 & & & -0.0277 & -0.0322 & & \\
\hline Log-likelihood & -241.444 & & & & -340.112 & & & \\
\hline
\end{tabular}

Table 6- ATE and ATET of production and gross profit

\begin{tabular}{ccccc}
\hline \multirow{2}{*}{ Variables } & \multicolumn{2}{c}{ Production } & \multicolumn{2}{c}{ Gross profit } \\
\cline { 2 - 5 } & Coefficient & $t$-value & Coefficient & t-value \\
\hline ATE & $1.176^{* * *}$ & 3.135 & 0.080 & 0.110 \\
ATT & $1.262^{* * *}$ & 3.020 & 0.078 & 0.100 \\
\hline
\end{tabular}

***, significant at $1 \% ; * *$, significant at $5 \% ; *$, significant at $10 \%$ 


\section{Conclusions}

Although the number of cattle and beef meat production has been substantially raised by means of supports in Turkey in recent years, the domestic production could not fulfill the demand of beef meat yet and therefore the demand has been met by a great amount of import. In this sense, the evaluation of the impacts of livestock supports on beef cattle farms is essential to analyze the efficiency of resource utilization, selfsufficiency, and sustainability of beef cattle sector. This research seeks to identify the impact of cattle breeding supports on production and income of beef cattle farms via the case of Samsun province.

The results of this study highlight that the farms have larger land and herd, specialized in beef cattle breeding, using modern devices and machines, and keeping records were more likely to benefit from livestock supports than their counterparts. The essential result of the study indicates that the supports could increase the production and income of the farms. Nevertheless, the cattle breeding supports had only a statistically significant effect on the beef meat production. As the supports had a significant contribution to the self-sufficiency of beef meat production, the farms should be continuously supported in order to increase the production in spite of no effect on gross profit. The statistical insignificance of gross profit model can be explained with the inability of farms to transform the physical product to fiscal return. The reason why the farms could not able to achieve sufficient gross profit can be explained by about half of the farms have lack of record and could be hardly managed. Therefore, cattle farms should be encouraged to keep financial records via mandatory of Farm Accountancy Data Network and supports should be revised in the form that the more detail financial record the farms have, the more support they could be granted. Although the specialization of about half of the farms in beef cattle breeding is essential, the dependency on external input for breeding cattle has increased the farm costs. This dependency raises the requirement of capital and reduces the economic profitability and sustainability in the long run. The supports would be effective in this sense and they should be revised in order to encourage the farms to produce their own breeding cattle and reduce the costs.

Cross-sectional and province-based data were used in this study. Therefore, it is proposed that the data should be expanded to regional and countrywide studies using either panel or single cross-sectional data in order to consider the wide perspective of the sector. Future researches should also examine all supply chain of beef meat sector. In this study, only support based economic sustainability was examined. It is also recommended that social, environmental and politic sustainability of the cattle farming should be analyzed in order to get a complete view of the sector.

\section{Acknowledgements}

This study is quoted from a part of the PhD thesis of Nevra ALHAS EROĞLU. It was supported by The Scientific and Technological Research Council of Turkey and Ondokuz Mayis University.

\section{References}

Acs S, Hanley N, Dallimer M, Gaston K J, Robertson P, Wilson P \& Armsworth P R (2010). The effect of decoupling on marginal agricultural systems: Implications for farm incomes, land use and upland ecology. Land Use Policy 27(2): 550-563

Aksoy A, Terin M \& Keskin A (2012). Türkiye süt sığırcılığında 1slah ve destekleme politikalarının bölgesel etkileri üzerine bir araştırma. Atatürk Üniversitesi Ziraat Fakültesi Dergisi 43(1): 59-64

Alhas Eroğlu N (2017). Samsun ilinde hayvancılık desteklerinin besi işletmelerinin üretim ve gelirlerine etkileri. PhD Thesis, Ondokuz Mayis University (Published), Samsun, Turkey

Angrist J D (2001). Estimation of limited dependent variable models with dummy endogenous regressors: Simple strategies for empirical practice. Journal of Business and Economic Statistics 19(1): 2-28

Anonymous (2015). Kırmızı Et Stratejisi. Republic of Turkey, Ministry of Agriculture and Forestry, General Directorate of Livestock, Ankara, Turkey 
Anonymous (2016). http://www.tuketbir.org.tr/basin_detay.asp?gidenID=MzI=

Anonymous (2018). Kalkınma Bakanlığı, 11. Kalkınma Planı, Tarım ve Gıdada Rekabetçi Üretim, Özel İhtisas Komisyonu Raporu, Ankara, Turkey

Aydın E, Can M F, Aral Y, Cevger Y \& Sakarya E (2010). Türkiye'de canlı hayvan ve kırmızı et ithalatı kararlarının sı̆̆ır besicileri üzerine etkileri. Veteriner Hekimler Derne ği Dergisi 81(2): 51-57

Bartolini F \& Viaggi D (2013). The common agricultural policy and the determinants of changes in EU farm size. Land Use Policy 31: 126-135

Breen J P, Hennessy T C \& Thorne FS (2005). The effect of decupling on the decision to produce: An Irish case study. Food Policy 30(2): 129-144

Chau N H \& De Gorter H (2000). Disentangling the production and export consequences of direct farm income payments. In: American Agricultural Economics Association Meetings, July 30-August 2, No: 21854, Tampa, Florida

Çelik C \& Sarıözkan S (2017). Kırşehir ili merkez ilçede sığır besiciliği yapan işletmelerin ekonomik analizi. Harran Üniversitesi Veteriner Fakültesi Dergisi 6(1): 38-45

Demir N (2009). Destekleme politikalarının hayvancılık sektörü üzerine etkilerinin bölgesel karşılaştırmalı analizi. PhD Thesis, Atatürk University (Published), Erzurum, Turkey

Demir N \& Yavuz F (2010). Hayvancılık destekleme politikalarına çiftçilerin yaklaşımlarının bölgelerarası karşılaştırmalı analizi. Atatürk Üniversitesi Ziraat Fakültesi Dergisi 41(2): 113-121

Douarin E, Bailey A, Davidova S, Gorton M \& Latruffe L (2007). Structural, location and human capital determinants of farmers' response to decoupled payments. EU FP6 Project IDEMA (Impact of Decoupling and Modulation in the Enlarged EU: a sectorial and farm level assessment), Deliverable 14

El Benni N, Finger R \& Mann S (2012). Effects of agricultural policy reforms and farm characteristics on income risk in Swiss agriculture. Agricultural Finance Review 72(3): 301-324

FAO (2018). Databases. Retrieved in September 10, 2018 from http://www.fao.org/faostat/en/\#data/QV

Genius M, Karagiannis G \& Tzouvelakas V (2008). Assessing European farmers' intentions in the light of the 2003 CAP reform. In: Paper Presented at the $109^{\text {th }}$ European Association of Agricultural Economics (EAAE) Seminar "The CAP after the Fischer Reform: National Implementations, Impact Assessment and the Agenda for Future Reforms', 20-21 November, Viterbo, Italy

Giannoccaro G \& Berbel J (2013). Farmers' stated preference analysis towards resources use under alternative policy scenarios. Land Use Policy 31: 145-155

Goodwin B K \& Mishra A K (2005). Another look at decoupling: Additional evidence on the production effects of direct payments. American Journal of Agricultural Economics 87(5): 1200-1210

Goodwin B K \& Mishra A K (2006). Are "decoupled" farm payments really decoupled? An empirical evaluation. American Journal of Agricultural Economics 88(1): 73-89

Gorton M, Douarin E, Davidova S \& Latruffe L (2008). Attitudes to agricultural policy and farming futures in the context of the 2003 CAP reform: A comparison of farmers in selected established and new Member States. Journal of Rural Studies 24: 322-336

Heckman J J \& Robb R (1985). Alternative methods for evaluating the impact of interventions. Journal of Econometrics 30: $239-267$

Hennessy D (1998). The production effects of agricultural income support policies under uncertainty. American Journal of Agricultural Economics 80(1): 46-57

Hsieh Y (2009). Lecture Note on Treatment Effects Analysis. New York University, pp. 1 
Kazukauskas A, Newman C \& Sauer J (2014). The impact of decoupled subsidies on productivity in agriculture: acrosscountry analysis using micro data. Agricultural Economics 45: 327-336

Keskin A, Dağdemir V \& Yavuz F (2010). Türkiye et sığırcılığında ıslah ve destekleme politikalarının bölgesel etkileri üzerine bir çalışma. In: Türkiye 9. Ulusal Tarım Ekonomisi Kongresi, 22-24 Eylül, Şanlıurfa, Türkiye

Latruffe L, Dupuy A \& Desjeux Y (2013). What would farmers' strategies be in a no-CAP situation? An illustration from two regions in France. Journal of Rural Studies 32: (10-25). pp. 14

Lobley M \& Butler A (2010). The impact of CAP reform on farmers' plans for the future: some evidence from South West England. Food Policy 35(44): 341-348

Majewski E, Sulewski P, Raggi M \& Viaggi D (2011). Differences in possible reactions of EU farmers from selected European regions to CAP Change. Acta Scientiarum Polonorum Oeconomia 10(1): 45-56

Morgan-Davies C, Waterhouse T \& Wilson R (2012). Characterization of farmers' responses to policy reforms in Scottish hill farming areas. Small Ruminant Research 102(2-3): 96-107

Moss J, McErlean S, Kostov P \& Patton M (2002). Analysis of impact of decoupling on agriculture in the UK. Food and Agricultural Policy Research Institute, University of Missouri

O'Donoghue E J \& Whitaker J B (2010). Do direct payments distort producers' decisions? An examination of the Farm Security and Rural Investment Act of 2002. Applied Economic Perspectives and Policy 32(1): 170-193

Özkan U \& Erkuş A (2003). Bayburt ilinde sığır besiciliğine yer veren tarım işletmelerinin ekonomik analizi. Tarım Bilimleri Dergisi 9(4): 467-472

Özüdoğru T \& Tatlıdil F F (2012). Amasya Damızlık Sı̆̆ır Yetiştiricileri Birliğine üye olan ve olmayan işletmelerin ekonomik analizi ve süt sığırcılığına yönelik desteklerin gelire etkisi. Selçuk Tarım ve Gıda Bilimleri Dergisi 26(3): 42-29

Revell B \& Oglethorpe D (2003). Decoupling and UK agriculture: a whole farm approach. Study Commissioned by DEFRA, London

Rubin D B (1974). Estimating casual effects of treatments in randomized and nonrandomized studies. Journal of Educational Psychology 66(5): 688-701

Sckokai P \& Moro D (2006). Modeling the reforms of the common agricultural policy for arable crops under uncertainty. American Journal of Agricultural Economics 88(1): 43-56

Severini S \& Tantari A (2013). The effect of the EU farm payments policy and its recent reform on farm income inequality. Journal of Policy Modeling 35: 212-227

Shrestha S, Hennessy T \& Hynes S (2007). The effect of decoupling on farming in Ireland: A regional analysis. Irish Journal of Agricultural and Food Research 46: 1-13

Terza J V (1998). Estimating count data models with endogenous switching: sample selection and endogenous treatment effects. Journal of Econometrics 84(1): 129-154

Topçu Y (2008). Çiftçilerin tarımsal destekleme politikalarından faydalanma istekliliğinde etkili faktörlerin analizi: Erzurum ili örneği. Akdeniz Üniversitesi Ziraat Fakültesi Dergisi 21(2): 205-212

Topçu Y, Uzundumlu A S \& Kızıloğlu S (2008). Sığır besiciliği işletmelerinin başarısızlığında etkili faktörlerin analizi: Erzurum ili örneği. Alınteri 15(B): 19-25

TURKSTAT (2018a). Retrieved in agricultural prices and economic accounts and livestock statistics. Retrieved in September 10, 2018 from http://www.tuik.gov.tr/PreTablo.do?alt_id=1004

TURKSTAT (2018b). Retrieved in crop production statistics. Retrieved in September 10, 2018 from https://biruni.tuik.gov.tr/bitkiselapp/bitkisel.zul 
TURKSTAT (2018c). Retrieved in statistical indicators, regional statistics. Retrieved in September 10, 2018 from https://biruni.tuik.gov.tr/bolgeselistatistik/tabloOlustur.do\#

Viaggi D (2011). Approaches to research in support to agricultural policy: The experience of the CAP-IRE Project. Acta Scientiarum Polonorum Oeconomia 10(2): 83-94

Weber J G \& Key N (2012). How much do decoupled payments affect production? An instrumental variable approach with panel data. American Journal of Agricultural Economics 94(1): 52-66

Yamane T (2001). Elementary Sampling Theory. Prentice Hall Inc., Englewoods, New Jersey

Yılmaz H, Demircan V \& Dernek Z (2008). Türkiye tarımında doğrudan gelir desteği uygulamaları (Isparta ili üreticileri açısından bir değerlendirme). Doğuş Üniversitesi Dergisi 9(2): 248-265 